\title{
A Contrastive Survey of Speech Acts in Hong Kong Bilingual Legislative Texts: A Case Study of CO and SPR
}

\author{
Kefeng $\mathrm{Fu}^{1}$ \\ ${ }^{1}$ College of Humanities and Foreign Languages, Xi' an University of Science and Technology, China \\ Correspondence: Kefeng Fu, College of Humanities and Foreign Languages, Xi'an University of Science and \\ Technology, Lintong District, 710600 Xi'an, Shaanxi, China. Tel: 86-135-714-921-26. E-mail: \\ fkf2001@126.com
}

\author{
Received: February 24, 2014 Accepted: March 25, 2014 Online Published: April 14, 2014 \\ doi:10.5539/elt.v7n5p102 URL: http://dx.doi.org/10.5539/elt.v7n5p102
}

\begin{abstract}
As one kind of the legislative language, the language of bilingual legislation possesses its specific characteristics: the two versions share the same authenticity and effect. Therefore, the contrastive analysis of this kind of language from the perspective of pragmatics is more persuasive and authoritative. In this paper, the author chooses Crime Ordinance of Hong Kong and its subsidiary regulation Suppression of Piracy Regulations as data to explore the similarities and differences in the realization methods of speech acts and the frequency of speech acts indicators between English and Chinese texts. The author hopes to find conversions and translations of the corresponding form in speech acts of bilingual legislation and provide references for legal translation between English and Chinese through this study.
\end{abstract}

Keywords: speech act theory, Hong Kong bilingual legislation, contrast, comparison

\section{Introduction}

With the reunification of Hong Kong, the bilingual legislation of Hong Kong comes into people's eyes. Compared with the legal system of the People's Republic of China in the mainland (hereinafter referred to Mainland PRC), the legal system of Hong Kong is on the basis of the English common law, completed by Hong Kong's local legislation. For special historical reasons, as one of the Special Administrative Region of the PRC, the legal system of Hong Kong is different from that of the PRC. The author of the present study is interested in investigating and comparing the legal forces distributions in bilingual legislative texts of Hong Kong from the perspective of speech acts.

Laws, which regulate human's actions, are expressed through language. The law and language studies are being concerned and surveyed from many perspectives. Linguistic methods, a theoretical issue in language and law studies, are much employed to explore the inter-relationships among law, language and legislative forces. Speech act theory, a famous pragmatic approach, first proposed by Austin, has been developed and employed in all sorts of texts by many scholars afterwards. Speech act has long been recognized as being able to produce and create legal forces once it is employed in legal texts (Kurzon, 1986; Trosborg, 1995; Zhang, 2000; Cao, 2007). For a long time, speech act theory is applied to analyze legal discourses by some scholars. However such researches are conducted either merely on English legislative language (Habermas, 1981; Danet, 1985; Trosborg, 1991, 1995), or only on Chinese legislative language (Zhang, 2000; Cao, 2007, 2009). The author of the present paper finds a contrastive study between different kinds legislative texts (the author takes four Chinese statutory laws and their English counterparts in relation to intellectual property rights as research materials) from the perspective of speech acts (Ni \& Sin, 2011, pp. 375-384). However, till now, speech act theory is scarcely employed in same legislative text with two language versions (herein also refer to Bilingual legislation), not to mention Hong Kong bilingual legislative texts. Therefore, in the present study, the author tries to unveil the mystery of the bilingual legislative text of Hong Kong from the perspective of speech act theory.

\section{The Theoretical Perspectives of Speech Acts in Legal Context}

As we all know that Austin and Searle have categorized speech acts into different kinds from the perspective of the functions performed by speech acts. However, both of the categories are based on linguistic perspective without taking legal context into consideration. Habermas (1987) brought about his classifications, (i) regulative 
speech act, (ii) expressive speech act, and (iii) constative speech act. His classifications have taken the distinction between legal speech act and ordinary speech act into consideration, which merged the performative nature of legal language into the linguistic context (ibid). Compared with Austin's and Searle's classifications of speech acts, it's really a big step.

On the basis of Habermas, Trosborg has further developed and refined the categories of speech acts in legal context. Trosborg defines the language of the law as regulative, which serves as "ordering human relations" and "permitting". In a sense, speech acts applied in legislative language could be considered as directive legal speech acts, the application of which is to confer rights, impose obligations, prescribe prohibitions and grant permissions. For the specific purpose of directives, it could be concluded that a directive is an illocutionary act which aims to influence the behavior of the addressees.

After a brief review on speech act theory as well as speech act theory applied in legal language, the author has made following discoveries: (i) Speech act theory is applied into legal and legislative language study by several scholars, whose researches lie in reclassifying legal or legislative speech act from different perspectives (Danet, 1980; Habermas, 1981; Kurzon, 1986; Trosborg, 1995; Zhang, 2000; Cao, 2009); and in taking legislative speech acts into case studies or contrastive studies (Trosborg, 1991; Zhang, 2000; Cao, 2009). (ii) Their studies are mainly on English legislative texts, or barely on Chinese legislative texts, or on contrastive studies between English legislative texts and Chinese legislative texts.

Whereas, few researches have conducted on bilingual legislative texts, not to mention researches concerning the application of speech act theory into bilingual legislative texts of Hong Kong. Enlightened by the above discoveries, the author on the basis of Trosborg, Zhang \& Cao's classifications on legislative speech acts, will compare the use of legislative speech acts in bilingual legislative texts of Hong Kong (both the Chinese version and English version are adopted), and inspect and verify if Trosborg, Zhang \& Cao's classifications of the legislative speech acts indicators is applicable to the analysis of the legislative speech act in bilingual legislative texts of Hong Kong.

\section{Research Methodology}

\subsection{Data Collection}

The data, obtained from http://www.legislation.gov.hk/eng/index.htm, are the Hong Kong Crime Ordinance (hereinafter referred to $\mathrm{CO}$ ) and its attached regulations, the Suppression of Piracy Regulations (hereinafter referred to SPR). Both the English and Chinese versions of theses two involved texts are adopted to implement the present study. To make it convenient for computer analyzing, the author downloads the research data of PDF form from the website of Department of Justice Bilingual Law Information System of Hong Kong. Then, by using the software named PDF to Word, the author converts the PDF form of the research data into Microsoft Word and calculates the total words of that. The total words of the English versions are 41,670, and that of the Chinese versions are 65,978.

Hong Kong has practiced bilingual (English \& Chinese) legislation since its returning to China in 1997 (Li, 1997), and according to Section 10B of the Hong Kong Interpretation and General Clauses Ordinance, "the English language text and the Chinese language text of an Ordinance shall be equally authentic, and the provisions of an Ordinance are presumed to have the same meaning in each authentic text". Therefore, as a result of this distinctive feature, Hong Kong bilingual legislative texts are chosen to be the research data in the present study. Although a contrastive study between legislative speech acts in English and Chinese statutory laws has been made by $\mathrm{Ni}$ and Sin (2011, pp. 375-384), their study merely involves in statutory texts of the similar kind across different jurisdiction. By contrast, using the same authentic text as research data would be more faithfulness and accuracy to conduct the present study. Besides, the present study aims to explain the hidden legal forces (like right and obligation) of Hong Kong bilingual legislative texts from the perspective of speech act theory. Due to the strong manifestation of right and obligation in CO and SPR, the chosen research data would clearly interpret and illustrate the legal forces hidden in Hong Kong bilingual legislative texts.

\subsection{Categories of Legislative Speech Acts and the Indicators of the Present Study}

Section3.2 has suggested that scholars have already categorized legislative speech acts from different perspectives (Zhang, 2000; Trosborg, 1997). The goals of their studies are to reveal the hidden illocutionary forces in legislative texts by the use of different realization forms of the legislative speech acts (or IFID), but their classifications present a tendency of chaos. Therefore, in this study the author mainly adopts the classifications on legislative speech acts as well as legislative speech acts indicators suggested by Trosborg, and Zhang. Although their categories on legislative speech acts are conducted from different perspectives, the author 
of the present study mainly follows Trosborg's category, and categorizes legislative speech acts as directives from the perspective of the functions performed by speech acts. Meanwhile, combing the categories of legislative speech acts as well as the legislative speech acts indicators proposed by Zhang and Ni \&Sin, the author finally gets a framework of the category of legislative speech act and types of speech acts indicator as following table tells. As the previous discussion, on the basis of Trosborg, the author categorizes the legislative speech acts as directives from the perspective of function performed by speech acts. Based on this, the following two tables are presented.

Table 1. Legislative speech act indicators in English legislative texts

\begin{tabular}{|c|c|c|c|c|c|}
\hline & & \multicolumn{4}{|l|}{ Directive } \\
\hline & \multirow[t]{2}{*}{ Strategies } & \multicolumn{2}{|l|}{ Right } & \multicolumn{2}{|l|}{ Obligation } \\
\hline & & Permission & Right & Obligation & Prohibition \\
\hline \multirow[b]{2}{*}{ Performatives } & Speaker-based & $\begin{array}{l}\text { Allow grant, } \\
\text { offer, permit }\end{array}$ & N/A & demand, request & prohibit \\
\hline & Hearer-oriented & N/A & $\begin{array}{l}\text { Have } \\
\text { right/power } \\
\text { be entitle } \\
\text { to/ confer }\end{array}$ & $\mathrm{N} / \mathrm{A}$ & N/A \\
\hline \multirow[t]{2}{*}{ Modal Verbs } & Direct & N/A & N/A & $\begin{array}{l}\text { Must, } \\
\text { have to, be to, } \\
\text { shall, } \\
\text { should, } \\
\text { ought to, } \\
\text { would }\end{array}$ & $\begin{array}{l}\text { Can not, } \\
\text { must not, } \\
\text { shall not, } \\
\text { would not, } \\
\text { may not }\end{array}$ \\
\hline & Indirect & Can, may & & N/A & N/A \\
\hline
\end{tabular}

Table 2. Legislative speech act indicators in Chinese legislative texts

\begin{tabular}{|c|c|c|c|c|c|}
\hline & \multirow{3}{*}{ Strategies } & \multicolumn{4}{|l|}{ Directive } \\
\hline & & \multicolumn{2}{|l|}{ Right } & \multicolumn{2}{|l|}{ Obligation } \\
\hline & & Permission & Right & Obligation & Prohibition \\
\hline \multirow[b]{2}{*}{ Performatives } & Speaker-based & $\begin{array}{l}\text { yunxu(允许) } \\
\text { shouquan(授权) }\end{array}$ & N/A & N/A & $\begin{array}{l}\text { Wuquan (无权) } \\
\text { Jinzhi (禁止) } \\
\text { Buxu (不许) }\end{array}$ \\
\hline & Hearer-oriented & N/A & $\begin{array}{l}\text { xiangyou... } \\
\text { quanli } \\
\text { (享有...权利) } \\
\text { (fu)you... } \\
\text { quan(li) } \\
\text { (赋有...权利) }\end{array}$ & $\begin{array}{l}\text { chengdan... } \\
\text { yiwu } \\
\text { (承担...义务) } \\
\text { zhuijiu... } \\
\text { yiwu } \\
\text { (追究...义务) }\end{array}$ & N/A \\
\hline \multirow[b]{2}{*}{ Modal verbs } & Direct & N/A & N/A & Bixu (必须) & Bude (不得) \\
\hline & Indirect & $\begin{array}{l}\text { Ke/keyi } \\
\text { (可/可以) }\end{array}$ & N/A & $\begin{array}{l}\text { Ying/yingdang } \\
\text { (应/应当) }\end{array}$ & Bude (不得) \\
\hline
\end{tabular}

\section{Speech Acts in Bilingual Legislation of Hong Kong}

\subsection{Speech Acts in the English Versions of Hong Kong Bilingual Legislative Texts}

This part will further discuss and examine the occurring frequencies of the realization indicators, the choice of strategies for issuing illocutionary legislative forces in the English version of Hong Kong Bilingual Legislative texts.

\subsubsection{Occurrence of Indicators in English Versions}

The occurring frequencies of the realization indicators of the legislative speech acts in the English versions of 
Hong Kong Bilingual Legislative texts are listed in Table 3 as follows, which present the distribution of the indicators of legislative speech acts in percentage.

Table 3. Indicators in English versions of Hong Kong bilingual legislative texts

\begin{tabular}{|c|c|c|c|c|}
\hline Indicators & $\mathrm{CO}$ & SPR & Total & Percentage \\
\hline \multicolumn{5}{|c|}{ Performatives (Category A) } \\
\hline \multicolumn{5}{|c|}{ Permissions } \\
\hline Allow & 2 & 1 & 3 & $0.38 \%$ \\
\hline Grant & 8 & 4 & 12 & $1.52 \%$ \\
\hline Permit & 31 & 2 & 33 & $4.17 \%$ \\
\hline Offer & 6 & 0 & 6 & $0.76 \%$ \\
\hline \multicolumn{5}{|l|}{ Rights } \\
\hline Have the rights/power & 0 & 0 & 0 & $0.00 \%$ \\
\hline Confer & 10 & 0 & 10 & $1.26 \%$ \\
\hline Be entitled to & 4 & 0 & 4 & $0.51 \%$ \\
\hline \multicolumn{5}{|l|}{ Obligations } \\
\hline Demand & 1 & 0 & 1 & $0.13 \%$ \\
\hline Request & 1 & 0 & 1 & $0.13 \%$ \\
\hline \multicolumn{5}{|l|}{ Prohibitions } \\
\hline Prohibit & 8 & 0 & 8 & $1.01 \%$ \\
\hline Total & $9.87 \%$ & & & \\
\hline \multicolumn{5}{|c|}{$\begin{array}{l}\text { Modals Verbs (Category B) } \\
\text { Permissions }\end{array}$} \\
\hline Can & 4 & 1 & 5 & $0.63 \%$ \\
\hline May & 138 & 14 & 152 & $19.19 \%$ \\
\hline \multicolumn{5}{|l|}{ Obligations } \\
\hline Shall & 414 & 38 & 452 & $57.07 \%$ \\
\hline Should & 4 & 0 & 4 & $0.51 \%$ \\
\hline Ought to & 0 & 0 & 0 & $0.00 \%$ \\
\hline Must & 0 & 0 & 0 & $0.00 \%$ \\
\hline Have to & 0 & 0 & 0 & $0.00 \%$ \\
\hline Be to & 0 & 0 & 0 & $0.00 \%$ \\
\hline Would & 42 & 0 & 42 & $5.30 \%$ \\
\hline \multicolumn{5}{|l|}{ Prohibitions } \\
\hline Cannot & 5 & 0 & 5 & $0.63 \%$ \\
\hline Shall not & 46 & 3 & 49 & $6.19 \%$ \\
\hline Must not & 0 & 0 & 0 & $0.00 \%$ \\
\hline Would not & 5 & 0 & 5 & $0.63 \%$ \\
\hline Total & $90.13 \%$ & & & \\
\hline Total & & & 792 & $100 \%$ \\
\hline
\end{tabular}

NOTE: CO refers to the English version of Crime Ordinance of Hong Kong Special Administrative Region, SPR is short for the English version of Suppression of Piracy Regulations of Hong Kong Special Administrative Region.

The illocutionary forces, permissions, rights, obligations and prohibitions, issued by the above listed indicators in Table 3 are presented in both categories. Indicators for conferring rights are vacant in category B, so rights for issuing directives are not explored in category B. Table 3 illustrates that indicators as ought to, must, have to, be to, must not and have the right/power are absent in the involved bilingual legislative texts. However, shall, may, shall not present as principal indicators for setting out illocutionary forces. With a percentage of $90.13 \%$ of the total, it is clearly enough to get that the distributions and occurring frequencies of modal verbs for issuing illocutionary forces in the involved texts outnumber the performatives (with a percentage of $9.87 \%$ of the total). 
Therefore, it could be indicate that modal verbs are the principle indicators for producing and establishing illocutionary forces in the involved bilingual legislative texts of English versions.

\subsubsection{Choices of Strategies for Issuing Legislative Speech Acts}

In Section Three, it has been discussed that direct and indirect strategies can be used for the establishment of the legal forces by choosing modal verbs as indicators in legislative texts. Table 2 in Section Three presents that may and can are employed in the choice of indirect strategy for setting out illocutionary legal forces, and the rest in the choice of direct strategy. By carefully computing and observation, the author of the present study finds that the choice of direct strategy (with a percentage of 70.31\%) outnumbers the choice of indirect strategy (with a percentage of $19.82 \%$ ). The result shows a tendency that the choice of direct strategy plays a dominate role in producing illocutionary forces in the involved bilingual legislative texts in the current study.

As discussed in Section Three, speaker-based and hearer-oriented are two manners for issuing illocutionary forces by performatives. As illustrated in Table 2 of Section Three, it has been discussed that speaker-based and hearer-oriented strategies can be used for the producing and establishment of the legal forces by choosing performatives in legislative texts. From table 3, choices of hearer-oriented strategy are concerned with only three performative verbs or phrases as indicators, like have the right/power, be entitled to and confer, to set out legislative speech acts. Others belong to the choice of speaker-based strategy. After a delicate observation of Table 3, the choice of speaker-based strategy $(8.1 \%)$ ranks above the choice of hearer-based strategy $(1.77 \%)$ as presented in figure 1. Therefore, it could be concluded that the English versions of the involved bilingual legislative texts in the present study concerns more on the choice of speaker-based strategy.

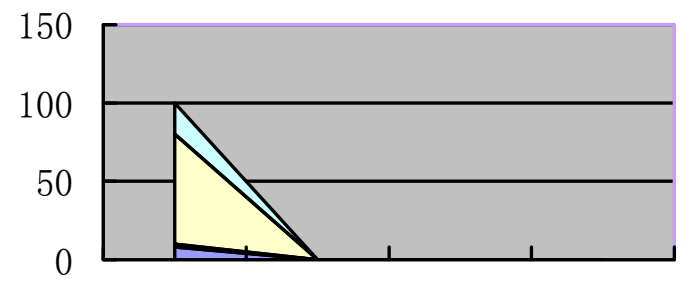

\begin{tabular}{|l|c|l|l|l|}
\hline$\square$ indirect & 19.82 & & & \\
\hline$\square$ direct & 70.31 & & & \\
\hline$\square$ heaer-oriented & 1.77 & & & \\
\hline$\square$ speaker-based & 8.1 & & & \\
\hline
\end{tabular}

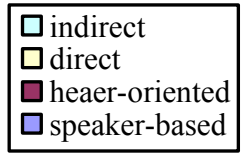

Figure 1. Distributions of strategies in English versions

\subsection{Speech Acts in the Chinese Versions of Hong Kong Bilingual Legislative Texts}

This part will further discuss and examine the occurring frequencies of the realization indicators, the choice of strategies for issuing illocutionary legislative forces in the Chinese versions of Hong Kong Bilingual Legislative texts.

\subsubsection{Occurrence of Indicators in Chinese Versions}

The occurring frequencies of the realization indicators of the legislative speech acts in the Chinese versions of Hong Kong Bilingual Legislative texts are listed in Table 4 as follows, which present the distribution of the indicators of legislative speech acts for issuing legal forces in percentage. 
Table 4. Occurrence of indicators in Chinese versions of Hong Kong bilingual legislative texts

\begin{tabular}{|c|c|c|c|c|}
\hline Indicators & $\mathrm{CO}$ & SPR & Total & Percentage \\
\hline \multicolumn{5}{|l|}{ Performatives(Category A) } \\
\hline \multicolumn{5}{|l|}{ Permissions } \\
\hline Yunxu 允许 & 0 & 0 & 0 & $0.00 \%$ \\
\hline Shouquan 授权 & 36 & 13 & 49 & $8.39 \%$ \\
\hline \multicolumn{5}{|l|}{ Rights } \\
\hline Xiangyou...quan(li) 享有......权(利) & 0 & 0 & 0 & $0.00 \%$ \\
\hline You...quan 有...权 & 19 & 0 & 19 & $3.25 \%$ \\
\hline (Fu)you...quan(li) (赋)有......权(利) & 0 & 0 & 0 & $0.00 \%$ \\
\hline \multicolumn{5}{|l|}{ Obligations } \\
\hline Chengdan...yiwu 承担......义务 & 0 & 0 & 0 & $0.00 \%$ \\
\hline Zhuijiu...yiwu 追究......义务 & 0 & 0 & 0 & $0.00 \%$ \\
\hline$(\mathrm{Fu})$ you...yiwu (赋)有...... 义务 & 0 & 0 & 0 & $0.00 \%$ \\
\hline You...yiwu 有...... 义务 & 0 & 0 & 0 & $0.00 \%$ \\
\hline \multicolumn{5}{|l|}{ Prohibitions } \\
\hline Wuquan 无权 & 6 & 0 & 6 & $1.03 \%$ \\
\hline Jinzhi 禁止 & 9 & 0 & 9 & $1.54 \%$ \\
\hline Buxu 不许 & 2 & 0 & 2 & $0.34 \%$ \\
\hline Total & 14.5 & & & \\
\hline \multicolumn{5}{|l|}{$\begin{array}{l}\text { Modal Verbs(Category B) } \\
\text { Permissions }\end{array}$} \\
\hline $\mathrm{Ke}$ 可 & 391 & 12 & 403 & $69.01 \%$ \\
\hline Keyi 可以 & 13 & 0 & 13 & $2.23 \%$ \\
\hline \multicolumn{5}{|l|}{ Obligations } \\
\hline Ying 应 & 16 & 0 & 16 & $2.74 \%$ \\
\hline Ying(dang) 应(当) & 0 & 0 & 0 & $0.00 \%$ \\
\hline Bixu 必须 & 5 & 0 & 5 & $0.86 \%$ \\
\hline \multicolumn{5}{|l|}{ Prohibitions } \\
\hline Bude 不得 & 50 & 9 & 59 & $10.10 \%$ \\
\hline Buying 不应 & 3 & 0 & 3 & $0.51 \%$ \\
\hline Total & 85.4 & & & \\
\hline Total & & & 584 & $100 \%$ \\
\hline
\end{tabular}

NOTE: CO refers to the Chinese version of Crime Ordinance of Hong Kong Special Administrative Region, SPR is short for the Chinese version of Suppression of Piracy Regulations of Hong Kong Special Administrative Region.

Corresponding to Table 3, in Table 4 legislative speech acts indicated by performatives are labeled as Category A, and that indicated by modal verbs are labeled as category B.

The illocutionary forces, permissions, rights, obligations and prohibitions, issued by the indicators listed in Table 4, appear in both categories. The same as that in the English version that indicators for conferring rights are absent in category B, so rights for issuing directives are not explored in category B. Like Table 3, Table 4 illustrates a prominent of modals $(85.45 \%)$ as indicators of legislative speech acts. However, indicators as yunx $u$ (允许), xiangyou...quan (li) (亭有......权(利)), (fu) you...quanli ((赋)有......权利), chengdan ...yiwu (承担...... 义务), zhuijiu...yiwu (追究......务), (fu) you...yiwu ((赋)有......义务), you ...yiwu (有...... 义务) and ying (dang) (应(当)) are absent in the involved bilingual legislative texts. Ke (可) and bude (不得) reveal as the principal indicators for issuing illocutionary legislative forces. Similar with the English Version of the involved bilingual legislative texts, Modal verbs are the principal realization of legislative speech act in the involved bilingual legislative texts of the Chinese versions.

\subsubsection{Choices of Strategies for Issuing Legislative Speech Acts}

In Section Three, the author has discussed that direct and indirect strategies can be used for the establishment of 
the legal forces by choosing modal verbs as indicators in legislative texts. Based on this, the author of this thesis has found that keyi (可以), ying/yingdang (应/应当), bude (不得) and buying (不应) are used indirect strategy for producing illocutionary forces in Chinese versions of the involved texts. And only two modal verbs, bude (不 得) and bixu (必须) are employed to be chosen as the direct strategy for issuing illocutionary forces. The result shows that Chinese versions of the involved bilingual legislative texts in the present research prefer the indirect strategy rather than the direct strategy.

As discussed in Section Three, speaker-based and hearer-oriented are two manners for issuing illocutionary forces by performatives. As illustrated in Table 2 of Section Three, speaker-based and hearer-oriented strategies can be used for producing legal forces by choosing performatives as indicators in legislative texts. Based on Table 4, it could be found that in the involved texts only a single phrase, you...quan (有......权) is concerned with the strategy of hearer-oriented. Words and phrases, as shouquan (授权), wuquan (无权), jinzhi (禁止) and bude (不得) are in the choice of speaker-based strategy. The calculation of Table 4 shows that the choice of speaker-based strategy accounts for $11.30 \%$, while hearer-oriented amounts only for $3.25 \%$. Hence, the author predicts that in the Chinese version of the involved bilingual legislative text, speaker-based strategy ranks above the hearer-oriented strategy. Details of the distribution of the choice of the strategies are presented in Figure 2.

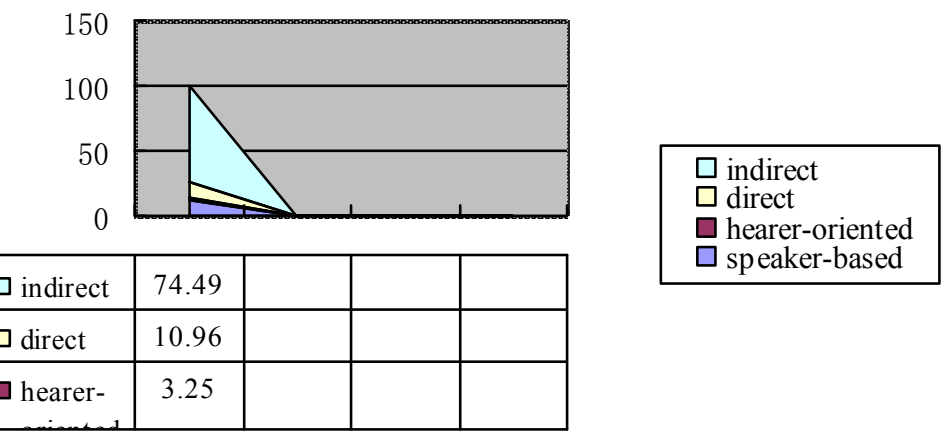

Figure 2. Distributions of strategies in Chinese versions

\subsection{Discussion}

Based on the discussion of the speech acts in the English versions and Chinese versions respectively, the author will discuss the similarities and differences of the speech acts in both the English and Chinese versions. Furthermore, the author will discuss the problems occurring in the course of the contrastive study of the indicators in the two versions.

\subsubsection{The Similarities and Differences of the Speech Acts in the Two Versions}

\subsubsection{Similarities}

For issuing illocutionary forces, the English and Chinese versions of the involved bilingual legislative texts display many similarities. Fossilized lexical items or phrases are employed as the indictors in both the English and Chinese versions for setting out illocutionary forces. On the other hand, modal verbs are much preferred than performatives by both the English versions and Chinese versions of involve legislative texts in the current research. Therefore, the author finally comes out the conclusion that modal verbs are predominate realization indicators of speech acts both in Chinese and English legislative texts, at least in the current study materials.

\subsubsection{Differences}

On the choice of strategies, the English versions prefer direct and speaker-based strategies in issuing legal forces, which account for $70.31 \%$ and $8.1 \%$, separately. In contrast, the Chinese versions prefer indirect strategy in setting out legislative forces, which amounts $74.49 \%$, while as for the choice of relationships between addresser and addressee, the Chinese version echoes with the English version, which emphasizes on the choice of speaker-based strategy. Figure 3 as follows will present a more vivid description. 


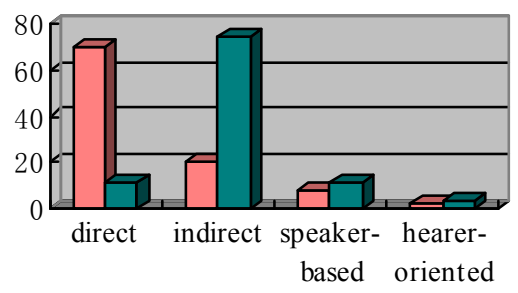

Figure 3. Comparison of strategy choices between English and Chinese versions

What's more, as for the distributions of legal forces, obligations rank first in English version, which account for a percentage of $63 \%$, and then come to permissions, prohibitions and rights. By comparing, in Chinese version permissions rank above all the other legal forces, which amount $79.72 \%$, then prohibitions, obligations, and rights. Figure 4 would be given to make it more vivid.

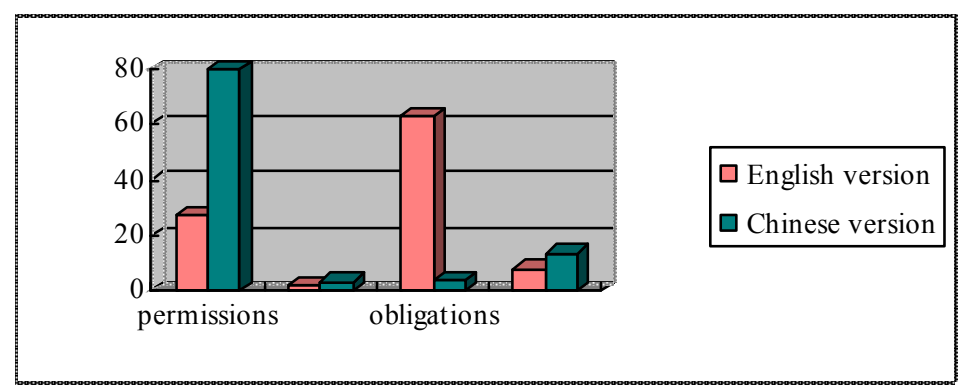

Figure 4. Comparisons of legislative forces distribution between English and Chinese versions

\section{References}

Austin, J. L. (1962, 1975). How to Do Things with Words. Cambridge, MA: Harvard University Press.

Danet, B. (1980). Language in the legal process. Law and Society, 14(3), 447-563.

Danet, B. (1985). Legal discourse. In V. Dijk (Ed.), Handbook of Discourse Analysis (Vol. 1, pp. 273-291). London: Acdamic Press Inc Ltd.

Garner, A. (2004). Black's Law Dictionary (8th ed.). New York: Thomson West.

Gibbons, J. (2003). Forensic Linguistics: An Introduction to Language in the Justice System. Oxford: Blackwell Publishing Ltd.

Habermas, J. (1981). Theorie des konununlkativen Handelns. Frankfurt AM Main: Suhrkam P.

Searle, J. R. (2001a). Speech acts: An essay in the philosophy of language. Beijing: Beijing Foreign Language Teaching and Research Press.

Tiersma, P. M. (1992). Legal Language. Chicago: University of Chicago Press.

Trosborg, A. (1991). An analysis of legal speech acts in English Contract Law. Journal of Linguistics, 6, 65-90.

Yule, G. (2000). Pragmatics. Shanghai: Shanghai Foreign Language Education Press.

\section{Copyrights}

Copyright for this article is retained by the author(s), with first publication rights granted to the journal.

This is an open-access article distributed under the terms and conditions of the Creative Commons Attribution license (http://creativecommons.org/licenses/by/3.0/). 